\title{
Biochemical changes and color properties of fresh-cut green bean (Phaseolus vulgaris L. cv.gina) treated with calcium chloride during storage
}

\author{
Rezzan KASIM ${ }^{1 \star}$, Mehmet Ufuk KASIM ${ }^{1}$
}

\begin{abstract}
Calcium chloride is widely used in industries as a firming agent, and also to extend shelf-life of vegetables. The aim of this study was to determine, the effect of different doses of calcium chloride on biochemical and color properties of fresh-cut green bean. Fresh-cut green beans were dipped for 90 seconds in $0.5 \%, 1 \%, 2 \%$ and $3 \%$ solution of calcium chloride at $25^{\circ} \mathrm{C}$. The fresh-cut green bean samples were packaged in polystyrene foam dishes, wrapped with stretch film and stored in a cold room at $5 \pm 1^{\circ} \mathrm{C}$ temperature and $85-90 \% \mathrm{RH}$. Calcium chloride treatments did not retain the green color of samples. Whiteness index, browning index and total color difference $(\Delta \mathrm{E})$ values of $\mathrm{CaCl}_{2}$ treated samples were high. Saturation index and hue angle were low compared to the control, especially at higher doses of $\mathrm{CaCl}_{2}$. Polyphenol oxidase (PPO) enzyme activity in samples treated with $\mathrm{CaCl}_{2}$ at $3 \%$ doses, was low at the $7^{\text {th }}$ days of storage than with other treatments. Fructose and sucrose content of samples increased in all treatment groups whereas glucose level decreased during the first $4^{\text {th }}$ days of storage.
\end{abstract}

Keywords: green bean; browning index; electrolyte leakage; polyphenol oxidase (PPO) activity; sugar content; whiteness index.

Practical Application: Improve fresh-cut green bean quality with calcium chloride applications.

\section{Introduction}

Phaseolus vulgaris, the green bean, is an herbaceous annual plant belonging to Fabaceae that originated in Central and South America. It is now cultivated in many parts of the world for its beans, which can be harvested and eaten immature, still in the edible pod, or when mature, shelled and dried. Green beans, which are high in vitamin $\mathrm{C}$ and dietary fibers, carbohydrates, proteins, and minerals (Brigide et al., 2014), are occasionally served fresh in salads but are more often prepared as a cooked vegetable. Green beans are often sold canned or frozen. Dried beans from this species are harvested when the pods have fully matured and dried (Courteau, 2012).

The consumption of minimally processed food products including ready-to-eat or ready-to-use has increased worlwide during the last decade due to their convenience, freshness and improved quality (Baskaran et al., 2007). However, minimally processed fresh fruit and vegetables are more perishable than their intact counterparts (Huxsoll \& Bolin, 1989). Ready-to-use products typically involve peeling, slicing, dicing or shredding prior to packaging and storage (Beuchat \& Brackett, 1990). Therefore, changes in the texture, flavor and appearance are limiting factors of the quality of minimally processed products.

Several preservation methods including antioxidant treatments, modified atmosphere packaging (MAP), refrigeration, chlorine wash (Ahn et al., 2005), ultraviolet irradiation (Kasım \& Kasım, 2008), $\gamma$-ray irradiation, chemical treatments such as with calcium lactate (Rico et al., 2007a), calcium chloride
(Saftner et al., 2003), citric acid, ascorbic acid are currently employed for commercial preparation of fresh-cut vegetables.

Green beans are generally harvested at a physiologically immature stage of development. Growth is rapid at the time of harvest and beans exhibit comparatively higher respiration rate, even when held at low temperatures (Watada \& Morris, 1967). Cutting of green bean also accelerates respiration rate more than in intact beans. Therefore, the quality of fresh-cut green bean decreases rapidly. In order to prevent the loss of quality of fresh-cut vegetables, several treatment methods are being practiced and calcium chloride treatment is one.

Calcium treatments have been widely used to extend the shelf-life of vegetables. Calcium helps to maintain the integrity of cell wall of vegetables by interacting with pectin to form calcium pectate. Calcium is reported to maintain firmness by cross-linking with cell wall and pectin of middle lamella. Thus, fruits and vegetables treated with calcium generally remain firmer than controls on storage (Rico et al., 2007a). Luna-Guzmán et al. (1999) found that when melons were dipped for $1 \mathrm{~min}$ in $2.5 \%$ calcium chloride solutions at 20 , 40 or $60^{\circ} \mathrm{C}$, firmness was maintained or improved, especially at higher dip temperatures.

The objective of this study was to determine the effects of post-harvest dips in calcium chloride on the biochemical responses of fresh-cut green beans. 


\section{Materials and methods}

\subsection{Plant material}

Green beans (Phaseolus vulgaris L. cv. Gina) grown in a field of Arslanbey Vocational School were harvested at the mature-green stage. Gina green bean variety has been improved by Asgrow Seed Co., and it is a hybrid of romano $\mathrm{x}$ unintroduced breeding line. The pods of plant is flat, and the seed inside of pods is white, also the plant is dwarf and growing as erect bush. After harvest, beans were immediately brought to the laboratory and washed in running tap water to remove dust and unwanted plant debris.

\subsection{Sample preparation}

After washing, beans were cut into pieces of $10 \mathrm{~cm}$-lenght and subjected to calcium chloride treatment by dipping for different periods of time in aqueous solution of calcium chloride;

\section{C: No treatment, control;}

F05: Fresh-cut green beans dipped in $0.5 \%$ aqueous solution calcium chloride for 90 second;

F1: Fresh-cut green beans dipped in 1\% aqueous solution calcium chloride for 90 second;

F2: Fresh-cut green beans dipped in $2 \%$ aqueous solution calcium chloride for 90 second;

F3: Fresh-cut green beans dipped in 3\% aqueous solution calcium chloride for 90 second.

\subsection{Packaging and storage conditions}

Fresh-cut green beans treated with calcium chloride were dried in a salad spinner for 60 second. Then beans were weighed $(135 \mathrm{~g})$, put in stored in polystyrene foam dishes (inner dimensions $13.5 \mathrm{~cm} \times 9 \mathrm{~cm} \times 2.5 \mathrm{~cm}$ ) wrapped completely with stretch film. After packaging, the beans were stored in a cold room set at $5^{\circ} \mathrm{C}$ temperature and $85-90 \%$ relative humidity.

\subsection{Color mesurement}

Color measurements ( $\mathrm{L}^{\star}, \mathrm{a}^{\star}$ and $\mathrm{b}^{\star}$ values) were performed using a chromameter CR-400 (Konica Minolta Inc. Osaka, Japan) with illuminant D65 with $8 \mathrm{~mm}$ aperture. The instrument was calibrated with a white reference tile $\left(\mathrm{L}^{*}=97.52, \mathrm{a}^{*}=-5.06\right.$, $\left.b^{\star}=3.57\right)$ prior to measurements. The $L^{*}(0=$ black, $100=$ white $)$, $\mathrm{a}^{\star}$ (+red, -green) and $\mathrm{b}^{\star}$ (+yellow, -blue) color coordinates were determined according to the CIELAB coordinate color space system.

Whiteness index (WI, Equation 1), saturation index (SI, Equation 2), hue angle ( $\mathrm{H}$, Equation 3$)$, total color difference $(\Delta \mathrm{E}$, Equation 4), and browning index (BI, Equation 5 and 6) were calculated using measured $\mathrm{L}^{*}, \mathrm{a}^{*}$ and $\mathrm{b}^{*}$ values as follows and used to determine the color changes as compared with control of fresh-cut green beans samples (Sarıçoban \& Yilmaz, 2010)

$\mathrm{WI}=100-\sqrt{\left(100-\mathrm{L}^{*}\right)^{2}+\mathrm{a}^{*^{2}}+\mathrm{b}^{*^{2}}}$
$S I=\sqrt{a^{*^{2}+b^{* 2}}}$

$\mathrm{H}=\arctan \left(b^{*} / a^{*}\right)$

$\Delta E=\sqrt{\left(L_{0}-L^{*}\right)^{2}+\left(a_{0}-a^{*}\right)^{2}+\left(b_{0}-b^{*}\right)^{2}}$

where subscript " 0 " refers to the colour reading of control sample used as the reference and a larger $\Delta \mathrm{E}$ indicates greater color change from the reference fresh-cut green bean samples.

$B I=\frac{100(x-0,31)}{0,17}$

Where (in Equation 5) $\times$;

$x=\frac{\left(a^{*}+1,75 L\right)}{\left(5,645 L^{*}+a^{*}-0,012 b^{*}\right)}$

\subsection{Sugar analysis}

$15 \mathrm{~mL}$ of water was addet $\mathrm{o} 3 \mathrm{~g}$ of fresh-cut green bean and the mixture was filtered through Whatman No. 1 filter paper, $20 \mu \mathrm{L}$ of filtrate was injected to HPLC system (Agilent, HP 1260, Hewlett Packard, CA/USA) with the following HPLC parameters: Column: Zorbax Carbohydrate Analysis, $4.6 \mathrm{~mm}$ ID $\times 150 \mathrm{~mm}(5 \mu \mathrm{m})$; Mobile phase: 75/25 acetonitrile/water; Flow rate: $1.4 \mathrm{~mL} / \mathrm{min}$; temperature: $30^{\circ} \mathrm{C}$; Detector $\mathrm{HP} 110 \mathrm{RID}, 30^{\circ} \mathrm{C}$, Sample volume: $20 \mu \mathrm{L}$ in 50/50 acetonitrile/water (Kasim et al., 2015).

\subsection{Polyphenol oxidase activity (PPO)}

To measure polyphenol oxidase activity, $5 \mathrm{~g}$ of homogenized fresh-cut green bean was extracted with $0.1 \mathrm{M}$ phosphate buffer, $\mathrm{pH} 7$ containing $5 \mathrm{~g}$ of polyvinylpyrrolidone using magnetic stirrer for $15 \mathrm{~min}$. The homogenate was filtered through Whatman No. 1 filter paper, and the filtrate collected as an enzyme extract. PPO activity was determined by a spectrophotometric method based on an initial rate of increase in absorbance at $410 \mathrm{~nm}$ (Soliva et al., 2000). Phosphate buffer pH 7 (0.1 M, $1.95 \mathrm{~mL})$, $1 \mathrm{~mL}$ of $0.1 \mathrm{M}$ catechol (substrate) and $50 \mu \mathrm{L}$ of the enzyme extract were pipetted into a test tube and mixed thoroughly. The mixture was rapidly transferred to a cuvete of path lenght $1-\mathrm{cm}$. The absorbance at $410 \mathrm{~nm}$ was recorded continuously at $25^{\circ} \mathrm{C}$ for 5 min using ultraviolet-visible (UV-VIS) spectrophotometer (UV Mini 1240, UV-VIS Spectrophotometer, Shimadzu, Japan) (Arnnok et al., 2010).

\subsection{Electrolyte leakage}

Electrolyte leakage (EL) was measured in discs $(5 \mathrm{~mm}$ diameter) cut out of the pods of fresh-cut green beans. The discs were washed several times with and subsequently incubated in distilled water. Conductivity was measured after $2 \mathrm{~h}$ of incubation. Total electrolyte conductivity in the discs was measured after freezing and thawing them. EL was calculated as the percentage of conductivity after $2 \mathrm{~h}$ (Kasım \& Kasım, 2014). 


\subsection{Visual quality assessment}

Visual quality was evaluated with reference to freshness, appearance, color, uniformity and brightness in a 5-points scale as follows: 5-Excellent; 4-Good quality, minor defects; 3-Fair quality, slightly to moderately objectionable defects; 2-Poor quality, excessive defects; 1-Extremly poor quality, not usable.

\subsection{Weight losses}

Weight of each sample with three replication of each treatment group was recorded on the day of harvest and on the sampling dates. Cumulative weight losses were expressed as percentage loss of original weight (Czaikoski et al., 2012).

\subsection{Statistical analysis}

Experiments were conducted in acompletely randomized design with a minimum of-three replications per storage treatments per sampling date. Data were analyzed by ANOVA and differences among means were determined by the Duncan's multiple range test with significance level at $\mathrm{p}<0.05$.

\section{Results and discussion}

\section{$3.1 a^{\star}$ values, Hue angle values and saturation index}

$a^{\star}$ values of fresh-cut green beans in all treatment groups were increased on the $4^{\text {th }}$ day of storage, and latter it started to decrease (Figura 1 ). At the $7^{\text {th }}$ day the lowest $a^{*}$ values was found for F3 treatment, and the differences between F3 treatment and control group was statistically significant $(\mathrm{p}<0.05)$. At the end of storage the lowest $\mathrm{a}^{*}$ value was obtained for F3 treatment group (-11.45) which was followed by F2 (-11.64), F1 (-12.71), F05 (-13.06) and C group (-13.38). Hue angle values and saturation index of samples in all treatment groups followed the same pattern as $\mathrm{a}^{\star}$ values (Figure 1 ). The primary criterion that the consumers consider about a product is its appearance; color has been considered to have a key role in the choice of food, food preference and acceptability, and may even influence taste thresholds, sweetness, perception and pleasantness. Color is one of the main attributes, along with texture, that characterizes the freshness of most vegetables (Rico et al., 2007b). In the present study, the green color of control group was remained until the end of storage period compared with samples treated with calcium chloride of different doses. Hence, it is understood that calcium chloride treatments have adverse effect on green color of fresh-cut green beans. Based on these results, it appears that calcium chloride application might have caused the breakdown of chlorophyll (data not shown).

\section{2 $L^{\star}$ Values and whiteness index}

$\mathrm{L}^{*}$ values of fresh-cut green beans samples in all treatment groups decreased during storage (Figure 2). But this decrease was relatively lower in F05 group than that of the other groups on the $7^{\text {th }}$ day after which $\mathrm{L}^{\star}$ values of samples in F3 group decreased sharply and also the differences between F3 treatment (62.63) and control group (65.93) were statistically significant $(\mathrm{p}<0.05)$.

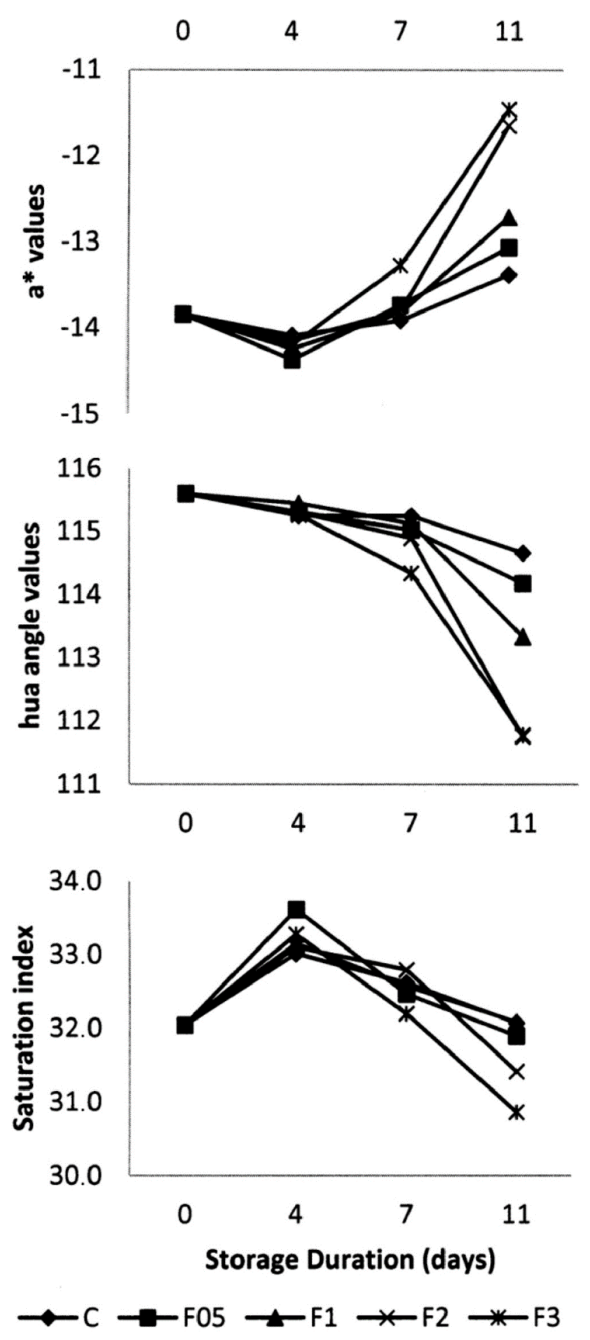

Figure 1. $a^{\star}$ values, hue angles values and saturation index of fresh-cut green bean samples.
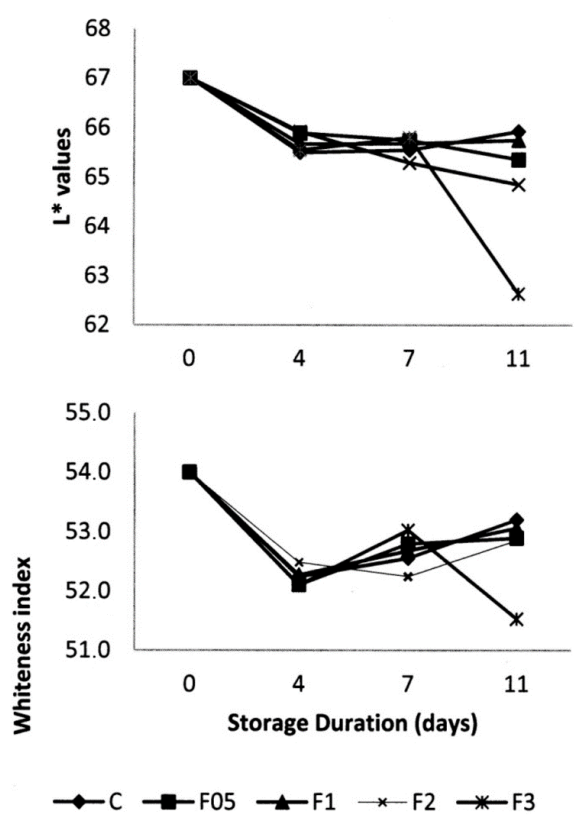

Figure 2. $\mathrm{L}^{*}$ values and whiteness index of fresh-cut green beans during 11 days of storage. 
Whiteness index decreased on the $4^{\text {th }}$ day of storage for all the different doses, and started to increased until the end of storage except for the F3 group (Figure 2). Lightness $\left(L^{*}\right)$ has been used by several researchers as an indicator of vegetable deterioration (Mastrocola \& Lerici, 1991). In this study, a decrease in $\mathrm{L}^{*}$ values of fresh-cut green beans in all treatment groups were observed on storage, and this result is correlated with whiteness index of samples. Since luminosity of samples treated with high doses of calcium chloride was low, it is believed that high doses of calcium chloride supress senescence in fresh-cut green bean samples.

\subsection{Browning index and $\Delta E$ values}

Browning indexes (BI) in all treatment groups increased marginally less compared to the initial values of the $7^{\text {th }}$ days of storage after which, BI increased sharply in all the gropus. This increase was found to be high especially in F3 treatment group, and also the differences between F3 treatment and control group were determined to be statistically significant $(\mathrm{p}<0.05)$. A similar trend, was also observed for $\Delta \mathrm{E}$ values in all treatment groups (Figure 3).

Total color difference $(\Delta \mathrm{E})$ which is a combination of parameters $\mathrm{L}^{*}, \mathrm{a}^{*}$ and $\mathrm{b}^{*}$ values, is a colorimetric parameter extensively used to characterize the variation in colors depending on processing conditions. In this study, $\Delta \mathrm{E}$ values were calculated with reference to the control-fresh-cut green beans. An increase (Figure 3) in $\Delta \mathrm{E}$ was observed in samples treated with high
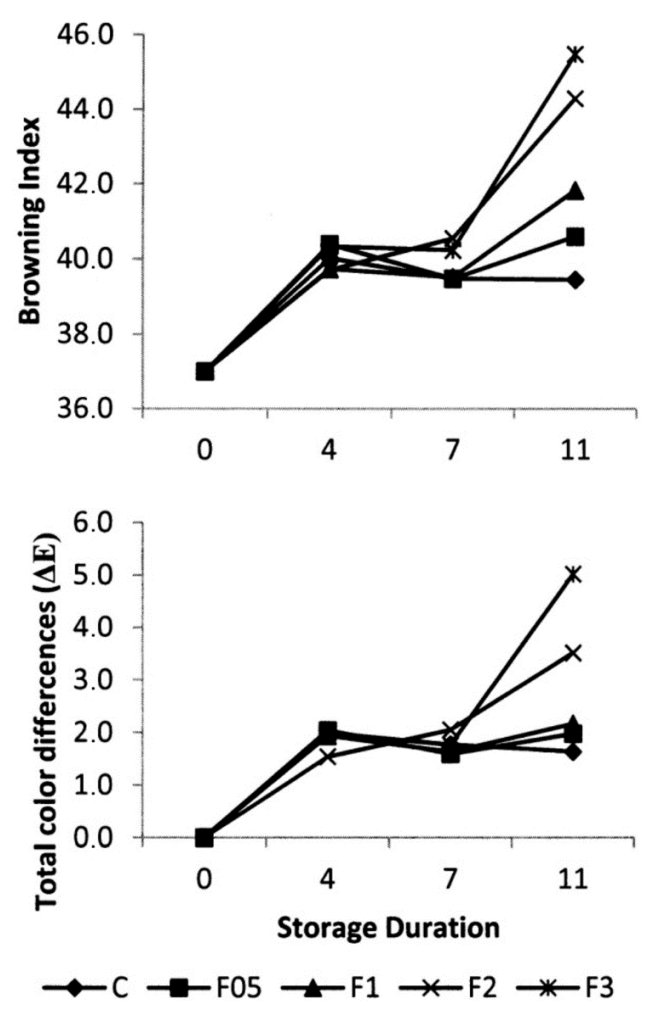

Figure 3. Browning index and total color difference $(\Delta \mathrm{E})$ values of fresh-cut green bean during storage. doses of calcium chloride. Eventually application of calcium chloride to fresh-cut green beans resulted in te change of green color of samples to pale-green color compared to the control.

\subsection{Sugar content of samples}

The fructose level of the control group increased during storage, while that of samples treated with calcium chloride initially increased during the first 4 days, followed by a decrease until the $7^{\text {th }}$ days of storage, and again started to increase. Hence the fructose level of samples presented an irregular profile (Figure 4). A similar pattern of change was observed the sucrose level of all the samples. The level of glucose in samples in all
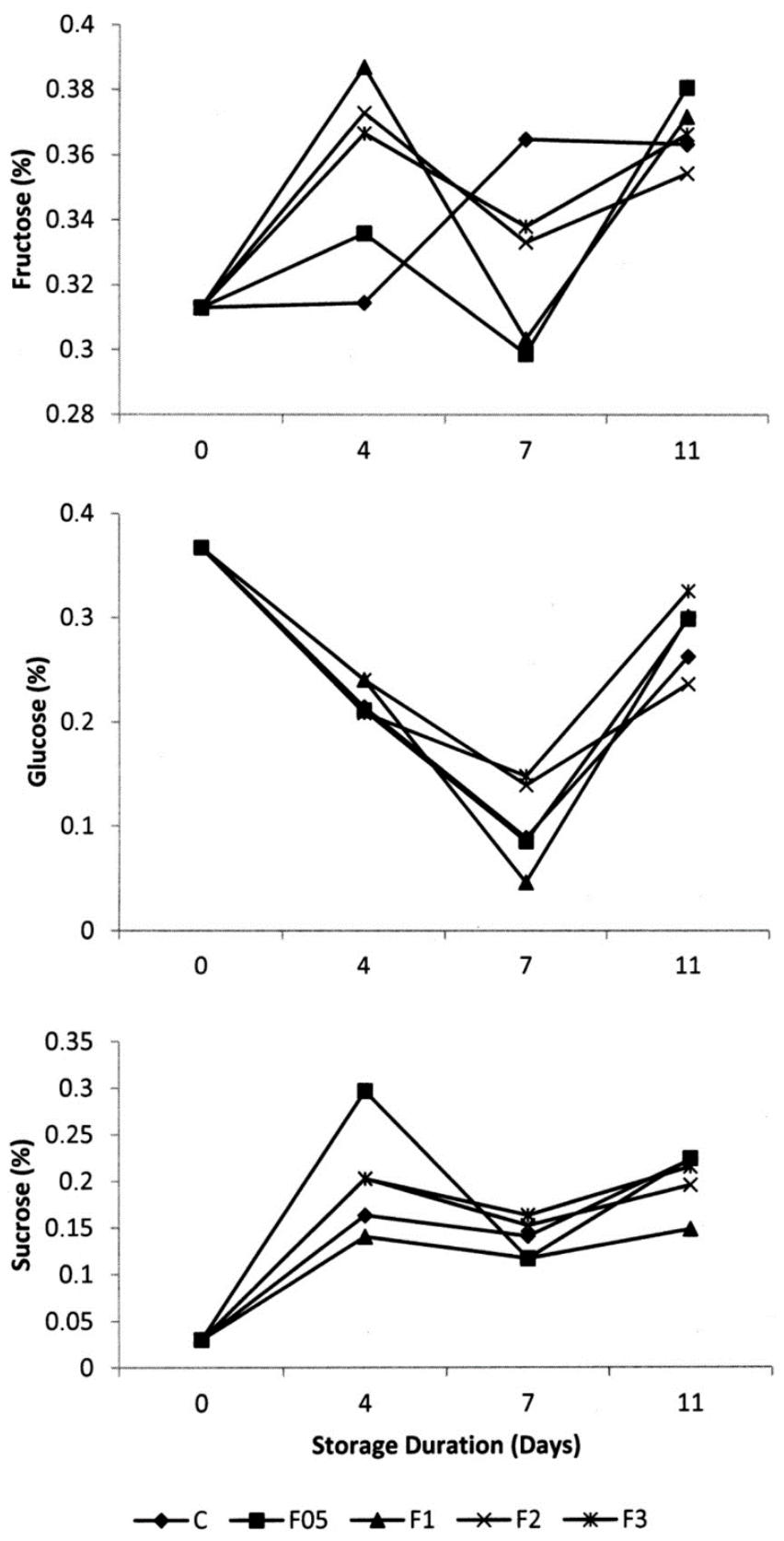

Figure 4. Sucrose, fructose and glucose values of fresh-cut green bean during storage. 
treatment groups, however, was decreased during the $7^{\text {th }}$ day of the storage, and subsequently increased at the end of the storage. This increase was found higher in F3 treatment group (0.33\%) compared to the other groups, and also the differences between F3 and F2 or control group were found statistically significant $(p<0.05)$. Changes in soluble sugars of stored vegetables are due to the balance between anabolic and catabolic processes.

In general, ripening involves a combination of both synthesis as well as degradation processes (Muñoz Delgado, 1985; Wills \& Gonzalez, 1998). All these processes involve interconversions of an array of different carbohydrates. In this study the level of sucrose in all the samples showed an increase during the whole period of storage. At $4^{\text {th }}$ day of storage, the level of sucrose was more than double from the initial values. After four days, the level of sucrose stabilized in all treatment groups. These data validate the synthesis of sucrose that takes place postharvest as reported previously by Parker \& Stuart (1935). These researchers reported that sucrose the main sugar in green bean seeds and that it increases in the pods during storage. The decrease in sucrose content is due to its degradation, releasing fructose and glucose for respiration. Similarly, the level of fructose in calcium chloride treated samples showed an irregular behaviour, while that of control group increased. In calcium chloride treated samples, fructose level was increased on $4^{\text {th }}$ days of storage. This phenomenon could be explained by an intense starch hydrolysis during this period. In contrast to the behavior of the leves of sucrose and fructose, the glucose content of samples decreased until the $7^{\text {th }}$ day, and then starts to increase. Sánchez-Mata et al. (2003) reported that in green bean pods, the level of glucose showed an irregular behavior and increased during the first 4-days of storage. But in the present study, it was found that glucose level of fresh-cut green bean decreased during the first day of storage and then started to increase. This might be due to the fact that an increase of rate of respiration depends on tissue disruption.

\subsection{Polyphenol Oxidase Activity (PPO)}

As shown in Figure 5, PPO activity of samples in F1 and F2 groups increased continuously during the storage period. In control and F05 treatments, however, the PPO activity decreased till $4^{\text {th }}$ day of storage and increased till $7^{\text {th }}$ day of storage, respectively and after that it decreased in latter condition.

Unlike the other groups, PPO activity of samples in F3 group decreased till the $7^{\text {th }}$ days of storage and then increased. PPO is an oxidative enzyme which catalyzes the oxidation of phenolic substrates and is responsible for enzymatic browning (Jiang et al., 2004). In the present study, PPO activity of samples in control or calcium chloride treated samples was found to be high except for the F3 group. These results suggest that polyphenol oxidase enzyme activity increases when green bean is cut. On the other hand PPO activity of samples in F3 group was found to be low. This might be due to the suppression of PPO activity by high dose of calcium chloride. Few studies have explored the influence of minimal processing operations on PPO activity. Buescher et al. (1974) reported that PPO activity increased when snap bean pods were broken and that the activity of phenolases was closely associated with the development of browning. Our results were consistent with these reports.

\subsection{Electrolyte leakage (EL)}

Electrolyte leakage (EL) of fresh-cut green bean samples decreased in all treatment groups except for F3 for the first 4 days of storage, and the differences between F3 and control group was found statistically significant $(\mathrm{p}<0.05)$. However an increase was observed on the $7^{\text {th }}$ day after which the EL of samples in all treatment group decreased. But in F3 treatment group EL of samples was stable until $7^{\text {th }}$ day of storage, after which it decreased (Figure 6). The electrolyte leakage of control group was lower than that of calcium chloride treated samples during storage. Hence, EL of fresh-cut green beans increased with high level of calcium chloride, and its application did not have inhibitory effect on EL of samples.

\subsection{Visual quality scores}

As shown in Figure 7, visual quality scores of samples in F3 remainer stable till the $4^{\text {th }}$ day whereas, it decreased in other treatment groups. The differences between F3 and other treatment groups were significant. At the $7^{\text {th }}$ day, visual quality

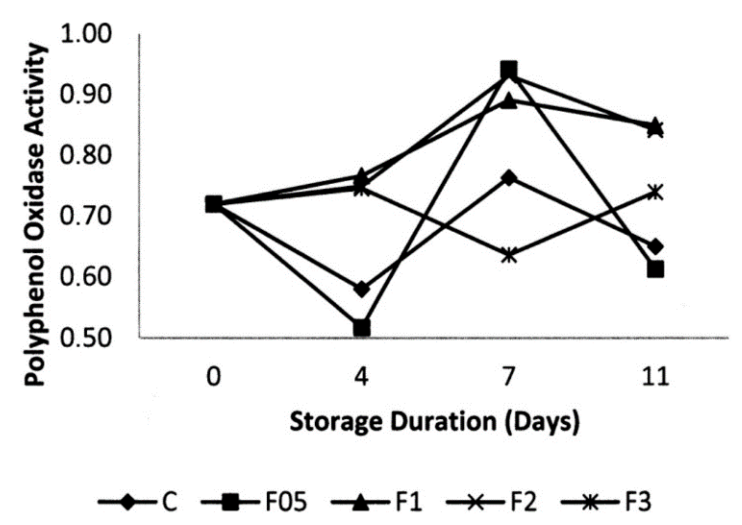

Figure 5. Polyphenol oxidase activity of fresh-cut green bean samples during storage.

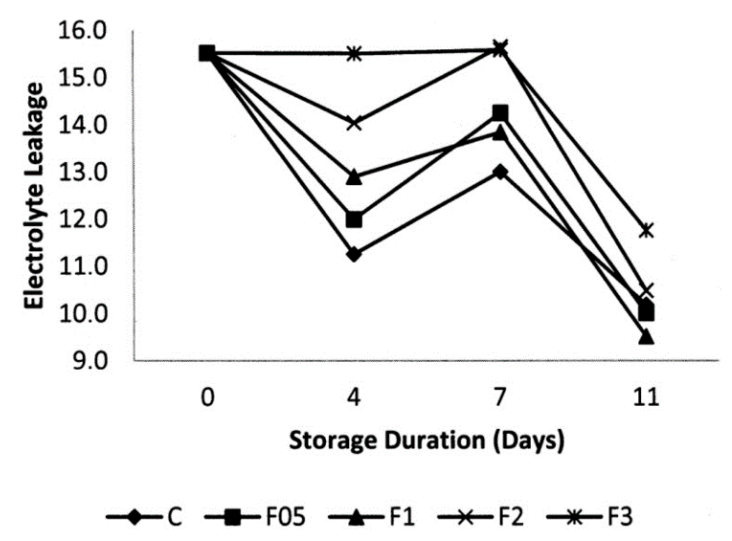

Figure 6. Electrolyte leakage of fresh-cut green bean treated with different doses of calcium chloride. 


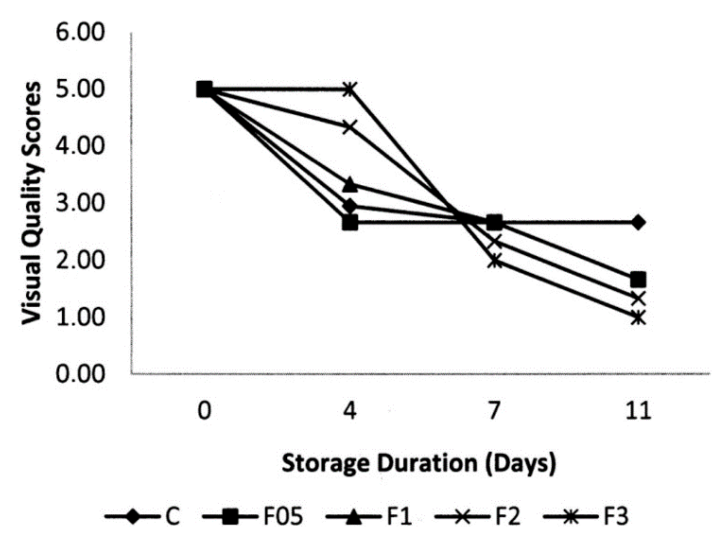

Figure 7. Visual quality scores of fresh-cut green bean samples.

scores of samples decreased below 3 points than the acceptable sales limit. This decrease continued until the end of period of storage, but this was lower in control group compared to calcium chloride treated samples. The differences between control and calcium chloride treated samples was found statistically significant $(\mathrm{p}<0.05)$.

The appearance of product is one of the most important criteria of quality. The value of fresh-cut fruits and vegetables to the costumer is determined by the quality posses. The quality of a product is a combination of an array of parameters, including appearance, texture, flavor and nutritional value. Also, consumers judge the quality of fresh-cut fruits and vegetables on the basis of appearance and freshness at the time of purchase (Rico et al., 2007b). In this study, calcium chloride treatments on fresh-cut green beans retained the quality for the first 4 days of storage compared to the control group, especially in F3 treatment group where in tha quality remained the same as the initial score. However after 4 days of storage, the effect of calcium chloride declined which might depend on the degree of absorption of calcium by the product, calcium chloride.

\section{Conclusions}

In this study, the effect of calcium chloride treatments on the quality of fresh-cut green bean was investigated. Calcium chloride treatment has been effective on the retention of color of samples for four days. Similarly, the level of fructose and sucrose of samples were high, but that of glucose was low. Polyphenol oxidase activity of samples has been reduced by high level of calcium chloride. Electrolyte leakage was blocked by high calcium chloride treatment, and the visual quality of samples treated with high calcium chloride was high. Hence it is suggested that calcium chloride treatments of fresh-cut green bean are effective to maintain quality for short period of storage.

\section{References}

Ahn, H. J., Kim, J. H., Kim, J. K., Kim, D. H., Yook, H. S., \& Byun, M. W. (2005). Combined effects of irradiation and modified atmosphere packaging on minimally processed Chinese cabbage (Brassica rapa L.). Food Chemistry, 89(4), 589-597. http://dx.doi.org/10.1016/j. foodchem.2004.03.029.
Arnnok, P. C., Ruangviriyachai, C., Mahachai, R., Techawongsrien, S., \& Chanthai, S. (2010). Optimization and determination of polyphenol oxidase and peroxidase activities in hot pepper (Capsicum annuum L.) pericarb. International Food Research Journal, 17, 385-392.

Baskaran, R., Usha Devi, A., Nayak, C. A., Kudachikar, V. B., Keshava Prakash, M. N., Prakash, M., Ramana, K. V. R., \& Rastogi, N. K. (2007). Effect of low-dose $\gamma$-irradiation on the shelf life and quality characteristics of minimally processed potato cubes under modified atmosphere packaging. Radiation Physics and Chemistry, 76(6), 1042-1049. http://dx.doi.org/10.1016/j.radphyschem.2006.10.004.

Beuchat, I. R., \& Brackett, R. E. (1990). Survival and growth of Listeria monocytogenes on lettuce as influenced by shredding, chlorine treatment modified atmosphere packaging and temperature. Journal of Food Science, 55(3), 755-758. http://dx.doi.org/10.1111/j.1365-2621.1990. tb05222.x.

Brigide, P., Canniatt-Brazaca, S. G., \& Silva, O. (2014). Nutritional characteristics of biofortified common beans. Food Science and Technology (Campinas.), 34(3), 493-500. http://dx.doi.org/10.1590/1678$457 x .6245$.

Buescher, R. W., Reitmeier, C., \& Sistrunk, W. A. (1974). Association of phenylalanine ammonia lyase, catecholase, peroxidase, and total phenoilic content with brown-end discoloration of snap bean pods. HortScience, 9(6), 585.

Courteau, J. (2012). Phaseolus vulgaris L. Retrieved from http://eol. org/pages/645324/overview

Czaikoski, K., Carrao-Panizzi, M. C., Silva, J. B., \& Ida, E. I. (2012). Effect of storage time and temperature on the characteristics of vegetable-type soybbean grain minimally processed. Brazilian Archives of Biology and Technology, 55(4), 491-496. http://dx.doi. org/10.1590/S1516-89132012000400002.

Huxsoll, C. C., \& Bolin, H. R. (1989). Processing and distribution alternatives for minimally processed fruits and vegetables. Food Technology, 43(2), 124-128.

Jiang, Y., Duan, X., Joyce, D., Zhang, Z., \& Li, J. (2004). Advance in understanding of enzymatic bowning in harvested litchi fruit. Journal of Food Chemistry, 88(3), 443-446. http://dx.doi.org/10.1016/j. foodchem.2004.02.004.

Kasım, M. U., \& Kasım, R. (2008). Double-sided UV-C treatments delayed chlorophyll degradation but increased chilling injury of green bean (Phaseolus vulgaris L. cv. Helda) during storage. Journal of Food Agriculture and Environment, 6(3-4), 176-180.

Kasım, R., \& Kasım, M. U. (2014). Biochemical and color changes of fresh-cut melon (Cucumis melo L. cv. Galia) treated with UV-C. Food Science and Technology (Campinas), 34(3). http://dx.doi. org/10.1590/1678-457x.6398.

Kasım, R., \& Kasım, M.U. \& Özer Uyar, G.E. (2015). Postharvest ascorbic acid treatments on color and sugar changes on fresh-cut carrot. International Journal of Research in Agriculture and Food Sciences, 2(10), 1-8. Retrieved from http://www.ijsk.org/wpcontent/uploads/2015/03/1-POSTHARVEST-ASCORBIC-ACIDTREATMENTS.pdf $</$ jrn $>$,

Luna-Guzmán, I., Cantwell, M., \& Barrett, D. M. (1999). Fresh-cut cantaloupe: effects of $\mathrm{CaCl} 2$ dips and heat treatments on firmness and metabolic activity. Postharvest Biology and Technology, 17(3), 201-213. http://dx.doi.org/10.1016/S0925-5214(99)00048-4.

Mastrocola, D., \& Lerici, C. R. (1991). Colorimetric measurements of enzymatic and non enzymatic browning in apple purees. Italian Journal of Food Science, 3(4), 219-229. 
Muñoz Delgado, J. A. (1985). Refrigeración y congelación de alimentos vegetales (Informes, Vol. 2). Madrid: Fundaicion Espanola de la Nutricion. 88 p.

Parker, M. W., \& Stuart, N. W. (1935). Changes in the chemical compositon of green snap beans after harvest. Bulletin of The University of Maryland Agricultural Experiment Station, 383, 291-313.

Rico, D., Martín-Diana, A. B., Barat, J. B., \& Barry-Ryan, C. (2007b). Extending and measuring the quality of fresh-cut fruit and vegetables; a review. Trends in Food Science \& Technology, 18(7), 373-386. http:// dx.doi.org/10.1016/j.tifs.2007.03.011.

Rico, D., Martín-Diana, A. B., Frias, J. M., Barat, J. M., Henehan, G. T. M., \& Barry-Ryan, C. (2007a). Improvement in texture using calcium lactate and heat-shock treatments for stored ready-to-eat carrots. Journal of Food Engineering, 79(4), 1196-1206. http://dx.doi. org/10.1016/j.jfoodeng.2006.04.032.

Saftner, R. A., Bai, J., Abbott, J. A., \& Lee, Y. S. (2003). Sanitary dips with calcium propionate, calcium chloride, or a calcium amino acid chelate maintain quality and shelf stability of fresh-cut honeydew chunks. Postharvest Biology and Technology, 29(3), 257-269. http:// dx.doi.org/10.1016/S0925-5214(03)00041-3.
Sánchez-Mata, M. C., Cámara, M., \& Díez-Marqués, C. (2003). Extending shelf-life and nutritive value of green beans (Phaseolus vulgaris L.) by controlled atmosphere storage: macronutrients. Food Chemistry, 80(3), 309-315. http://dx.doi.org/10.1016/S0308-8146(02)00265-0.

Sarıçoban, C., \& Yılmaz, M. T. (2010). Modelling the effects of processing factors on the changes in colour parameters of cooked meatballs using resporse surface methodology. World Applied Sciences Journal, 9(1), 14-22.

Soliva, R. C., Elez, P., Sebastian, M., \& Martin, O. (2000). Evaluation of browning effect on avocado purée preserved by combined methods. Innovative Food Science \& Emerging Technologies, 1(4), 261-268. http://dx.doi.org/10.1016/S1466-8564(00)00033-3.

Watada, A. E., \& Morris, L. L. (1967). Growth and respiration patterns of snap bean fruits. Plant Physiology, 42(6), 757-761. http://dx.doi. org/10.1104/pp.42.6.757. PMid:16656567

Wills, R., \& Gonzalez, J. B. (1998). Introduccion a la fisiologia manipulacion postcosecha de frutas, hortalizas y plantas ornamentales. Zaragoza: Acribia. 240 p. 